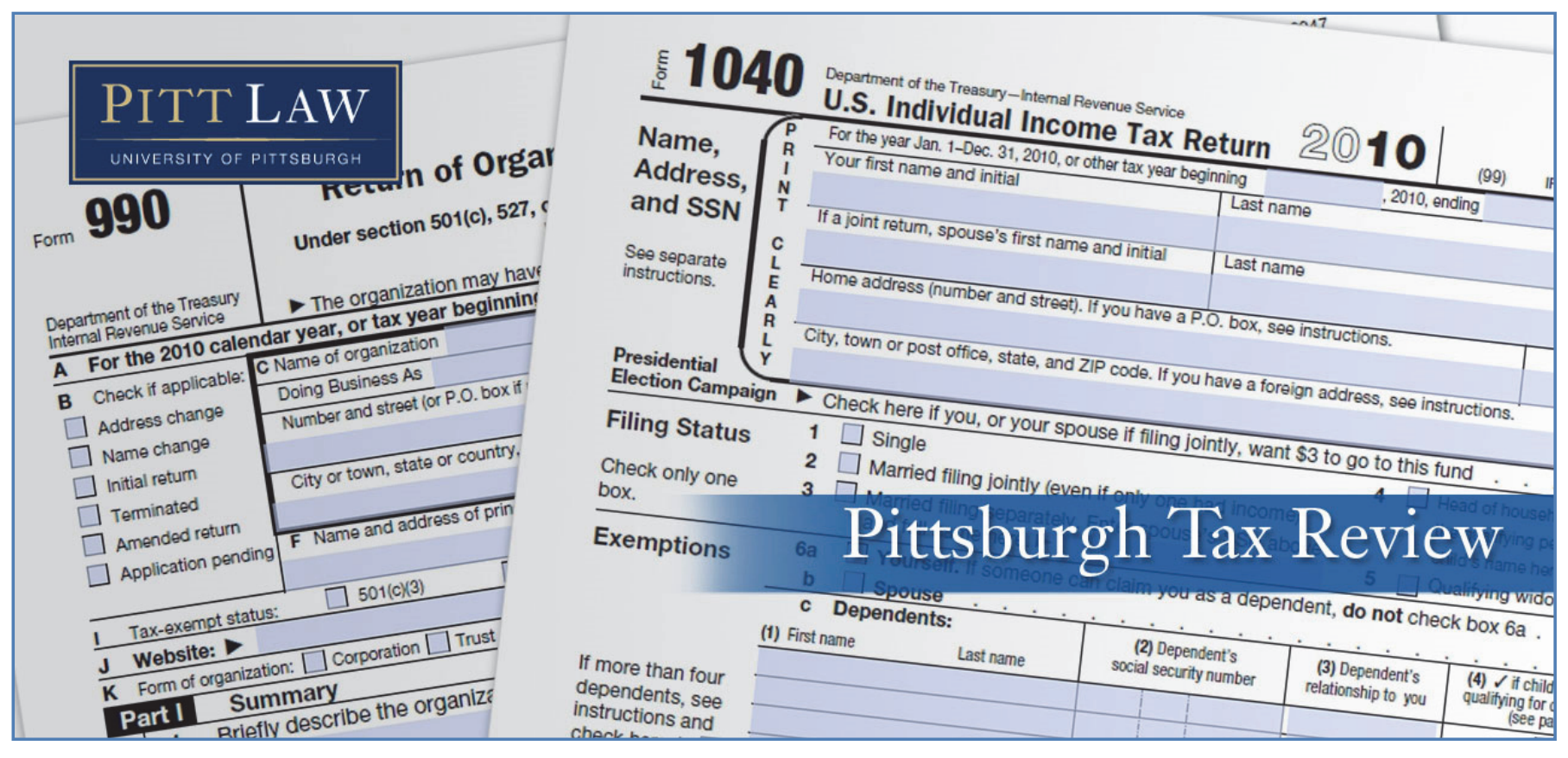

Volume 15 (2018) | ISSN 1932-1821 (print) 1932-1996 (online)

DOI 10.5195/taxreview.2018.74 | http://taxreview.law.pitt.edu

\title{
CHICAGO CITIZENS UNAMUSED BY CHICAGO'S EXPANDED \\ AMUSEMENT TAX
}

\section{Danielle Santoro}

\section{(cc) EY-NO-ND}

This work is licensed under a Creative Commons Attribution-Noncommercial-No Derivative Works 3.0 United States License.

\section{ULLS D-Sork}

This journal is published by the University Library System of the University of Pittsburgh as part of its D-Scribe Digital Publishing Program, and is cosponsored by the University of Pittsburgh Press. 


\title{
CHICAGO CITIZENS UNAMUSED BY CHICAGO'S EXPANDED AMUSEMENT TAX
}

\author{
Danielle Santoro*
}

\section{INTRODUCTION}

On July 1, 2015, Chicago extended its nine percent amusement tax to include certain streaming services delivered electronically by adopting a tax ruling, Amusement Tax Ruling No. 5. ${ }^{1}$ The amusement tax originally applied to charges paid for the privilege to witness, view, or participate in amusements. ${ }^{2}$ As applied in the amusement tax, the term "amusement" includes any exhibition, performance, presentation, or show for entertainment purposes, any entertainment or recreational activity offered for public participation or on a membership or other basis, or paid television programming. ${ }^{3}$

The new ruling adds that the tax applies not only to the privilege of witnessing, viewing, or participating in amusements in person, but also captures amusements that are delivered electronically. ${ }^{4}$ Thus, charges for streaming or renting shows, movies, videos, music, and games are now subject to the amusement tax. However, the expanded tax does not apply to purchases of shows, movies, videos, music, or games that are permanently

\footnotetext{
* JD, University of Pittsburgh School of Law 2017. This article represents the views of the author only and does not necessarily represent the views or professional advice of KPMG LLP. The information contained herein is of a general nature and based on authorities that are subject to change. Applicability of the information to specific situations should be determined through consultation with your tax adviser.

${ }^{1}$ See Chi. Dep't of Fin., Amusement Tax Ruling No. 5, City of Chicago 1, 3 (June 9, 2015), https://www.cityofchicago.org/content/dam/city/depts/rev/supp_info/TaxRulingsandRegulations/Amuse mentTaxRuling_5_06_09_2015.pdf.

${ }^{2} I d$.

${ }^{3}$ Second Amended Complaint for Declaratory \& Injunctive Relief at 16, Labell v. City of Chicago, No. 2015 CH 13399 (Cook Cty. Cir. Ct. Oct. 12, 2016).

${ }^{4} I d$. at $19-21$.
}

Pitt Tax Review | ISSN 1932-1821 (print) 1932-1996 (online)

DOI 10.5195/taxreview.2018.74 | http://taxreview.law.pitt.edu 


\section{8 |Pittsburgh Tax Review |Vol. 152018}

downloaded. ${ }^{5}$ For a streaming charge to be subject to the amusement tax, the billing address associated with the purchase must be in Chicago. ${ }^{6}$

While the idea of the expanded amusement tax appears to be simple, ${ }^{7}$ there are many complexities associated with it. The purpose of expanding Chicago's amusement tax to include purchases of amusements delivered electronically appears to be driven by the present-day shift in the preferences of consumers. ${ }^{8}$ A large percentage of the marketplace now prefers to consume electronically delivered entertainment rather than in-person entertainment. Therefore, the potential to raise revenue through taxing electronically delivered entertainment seems logical from the government's perspective because tax revenues raised from traditional entertainment sources are decreasing with this shift in preferences.

Taxing electronically delivered entertainment is a way to raise new revenue at a time when many states and localities are experiencing fiscal difficulties. Some of these challenges are attributed to a shift in how people seek amusement and shop. For example, "[s]tate and local governments are losing a significant amount of revenue by not being able to require remote vendors to collect the sales/use tax." Chicago's need to find new ways to generate tax dollars is intensified because the city is experiencing widespread financial problems and because it is also collecting less in tax dollars than in previous years. ${ }^{10}$ Many workers and businesses have left Chicago for more financially prosperous areas and taken their tax dollars with them. ${ }^{11}$ The

${ }^{5} I d$. at 22 .

${ }^{6} \mathrm{Id}$.

${ }^{7}$ Chi. Dep't of Fin., supra note 1.

${ }^{8}$ See Timothy Fallaw, Note, The Internet Tax Freedom Act: Necessary Protection or Deferral of the Problem?, 7 J. INTELL. PROP. L. 161, 162 (1999).

${ }^{9}$ Mark J. Cowan, Tax Planning Versus Business Strategy: The Rise and Fall of Entity Isolation in Sales and Use Taxes, 44 IDAHO L. REV. 63, 87 (2007) (estimating that, collectively, states lose between $\$ 21.5$ billion and $\$ 33.7$ billion of sales and use tax revenue per year).

${ }^{10}$ John Byrne \& Amina Elahi, Chicago Extends Taxing Power to Online Music, Movies, More, CHI. TRIB. (July 2, 2015, 6:30 AM), http://www.chicagotribune.com/news/local/breaking/ct-chicagocloud-tax-met-0702-20150701-story.html (citing Michael Reever, Vice President of Government Affairs at the Chicago Chamber of Commerce, who criticized the extended tax because it does not fix the root of Chicago's monetary problems).

${ }^{11} I d$.

Pitt Tax Review | ISSN 1932-1821 (print) 1932-1996 (online) DOI 10.5195/taxreview.2018.74 | http://taxreview.law.pitt.edu 
expansion of the amusement tax is expected to generate $\$ 12$ million annually for Chicago. ${ }^{12}$

Although expanding the amusement tax to include electronically delivered entertainment may appear to be a good economic strategy to raise tax dollars for Chicago, there are questions regarding the legality of this expansion and how it was accomplished. There is currently pending litigation, Labell v. City of Chicago, challenging the expanded tax. ${ }^{13}$ In Labell, the Liberty Justice Center, on behalf of six residents of Chicago, filed a complaint in the Circuit Court of Cook County on September 9, 2015. ${ }^{14}$ All six of the taxpayers subscribe to at least one online streaming or video gaming service and believe that the expanded amusement tax should be struck down in court. ${ }^{15}$ On the eve of publication of this Note, the court issued a decision in the case against the taxpayers and granting the City of Chicago's motion for summary judgment; however, the taxpayers have indicated their intent to appeal the adverse decision. ${ }^{16}$

This Note will discuss some points raised by the petitioners as well as other related ideas. First, this Note will consider whether the Chicago comptroller exceeded his authority by reinterpreting the existing amusement tax to include streaming services delivered electronically. Second, this Note will consider whether the taxation of internet-based services is preempted by the Federal Internet Tax Freedom Act. Third, this Note will consider whether the tax has violated the Commerce Clause. Fourth, this Note will briefly discuss other issues regarding the amusement tax.

\footnotetext{
${ }^{12}$ Id.; Kelly Phillips Erb, Cloud Tax Is the New Black: Chicago Tax Scheme Will Boost Costs for Services Like Netflix, FORBES (July 12, 2014, 7:14 AM), https://www.forbes.com/sites/kellyphillipserb/ 2015/07/12/cloud-tax-is-the-new-black-chicago-tax-scheme-will-boost-costs-for-services-likenetflix/\#3171deccf4a6.

${ }^{13}$ Second Amended Complaint, supra note 3.

${ }^{14} \mathrm{Id}$.

${ }^{15} \mathrm{Id}$.

${ }^{16}$ Labell v. City of Chicago, No. 15 CH 13399 (Cook Cty. Cir. Ct. May 24, 2018); see Michael J. Bologna, Chicago's "Netflix Tax" OK, but Appeal in Queue, DAILY TAX REP.: STATE, May 30, 2018, Bloomberg BNA (containing a link to the opinion and order).
}

Pitt Tax Review | ISSN 1932-1821 (print) 1932-1996 (online) DOI 10.5195/taxreview.2018.74 | http://taxreview.law.pitt.edu 


\section{$270 \mid$ Pittsburgh Tax Review | Vol. 152018}

\section{THE COMPTROLLER EXCEEDED THE SCOPE OF HIS AUTHORITY BY EXPANDING THE AMUSEMENT TAX IN AMUSEMENT TAX RULING No. 5}

The petitioners reasonably claim that Chicago's comptroller exceeded the scope of his authority by expanding the amusement tax. On June 9, 2015, Dan Widawsky, the comptroller of the City of Chicago, issued Amusement Tax Ruling No. 5 (the "Ruling") which added entertainment delivered electronically to the term "amusement" under Section 4-156-020(A) of the Municipal Code of Chicago, also known as the "amusement tax."17 According to the Ruling, amusements delivered electronically include: (1) streaming electronically delivered television; (2) streaming electronically delivered music; and (3) participating in games accessed online. ${ }^{18}$ However, prior to this Ruling, the amusement tax's definition of "amusement" did not include services streamed from the internet. ${ }^{19}$ The Ruling states that providers who receive charges for electronically delivered amusements are required to collect and remit the City's amusement tax from their Chicago customers. ${ }^{20}$

Under the Chicago Municipal Code, the comptroller has the authority to "adopt, promulgate and enforce rules and regulations pertaining to the interpretation, administration and enforcement" of the amusement tax. ${ }^{21}$ However, the Municipal Code does not authorize the comptroller to impose new taxes. ${ }^{22}$ If the comptroller wishes to impose a new tax, then a city ordinance must be created. According to the petitioners, as a result, any new additions to the amusement tax made by the comptroller, which go beyond interpreting the tax, are invalid. ${ }^{23}$

\footnotetext{
${ }^{17} I d$. at 18 .

${ }^{18}$ Plaintiffs' Motion for Summary Judgment at 3, Labell v. City of Chicago, No. 2015 CH 13399 (Cook Cty. Cir. Ct. Sept. 27, 2017).

${ }^{19}$ Second Amended Complaint, supra note 3, at 5.

${ }^{20}$ Plaintiffs' Motion for Summary Judgment, supra note 18, at 9.

${ }^{21}$ Second Amended Complaint, supra note 3, at 9.

${ }^{22} I d$. at 41 .

${ }^{23} \mathrm{Id}$. at 42 .
}

Pitt Tax Review | ISSN 1932-1821 (print) 1932-1996 (online) DOI 10.5195/taxreview.2018.74 | http://taxreview.law.pitt.edu 
When the comptroller promulgated the Ruling that extended the amusement tax to include amusements delivered electronically, he exceeded his authority. ${ }^{24}$ Further, if the City of Chicago wished to make this extension, then it should have enacted a new city ordinance through the powers of City Council. Accordingly, petitioners' argument that the comptroller did not have the authority to extend the amusement tax is justified.

\section{THE EXPANDED AMUSEMENT TAX Is PREEMPTED BY THE FEDERAL INTERNET TAX FREEDOM ACT}

The petitioners also argue that the Federal Internet Tax Freedom Act ("ITFA") preempts the amusement tax. ${ }^{25}$ This is also a valid argument. ITFA, passed in 1988, bans the levying of discriminatory internet-only taxes. ${ }^{26}$ ITFA defines a discriminatory internet-only tax as any tax imposed on electronic commerce that (1) is not imposed upon "similar property, goods, services, or information accomplished through other means" or (2) taxes "transactions involving similar property, goods, services, or information accomplished through other means" at a lower rate. ${ }^{27}$

This arguably means that nondiscriminatory taxes may be imposed on internet transactions, but taxes cannot be imposed that apply solely to online retailers. ${ }^{28}$ It also arguably means that internet and noninternet purchases that are similar must be taxed at the same rate. ${ }^{29}$ The expanded amusement tax discriminates against online entertainment by taxing purchases of streamed entertainment at a higher tax rate than ticket purchases for similar entertainment that is viewed live. Therefore, the petitioners' argument that the expanded amusement tax should be banned under ITFA is reasonable.

\footnotetext{
${ }^{24} I d$. at 45 .

${ }^{25}$ See 47 U.S.C. $\$ 151$ (2012).

${ }^{26}$ Id.; Internet Tax Freedom Act, Pub. L. No. 105-277, § 1101(a)(1), 112 Stat. 2681, 2681-719

${ }^{27}$ Second Amended Complaint, supra note 3, at 82 (citing 47 U.S.C. $\S 1105(2)(A)$ ).

${ }^{28}$ See Fallaw, supra note 8, at 168.

${ }^{29}$ See Second Amended Complaint, supra note 3, at 82.
} (1998).

Pitt Tax Review | ISSN 1932-1821 (print) 1932-1996 (online) DOI 10.5195/taxreview.2018.74 | http://taxreview.law.pitt.edu 


\section{2 |Pittsburgh Tax Review | Vol. 152018}

Under the Supremacy Clause of the U.S. Constitution, federal law is the "supreme law of the land." ${ }^{30}$ In Arizona v. United States, the Supreme Court of the United States held that laws made by Congress shall preempt state laws when: (1) Congress explicitly preempts state powers through express statutory language, (2) Congress intends to regulate an area and therefore precludes the states from doing so, or (3) state laws are inconsistent with federal law. ${ }^{31}$ Arguably, Chicago's expanded amusement tax triggers all three of these events that lead to preemption. ${ }^{32}$ This includes the argument that Chicago's amusement tax is a local law that is inconsistent with a federal law because ITFA, a federal law, bans taxes that discriminate against internet-only commerce and the expanded amusement tax, a local law, imposes a tax that discriminates against internet-only commerce. ${ }^{33}$

According to the petitioners, the expanded amusement tax is discriminatory because it applies to online entertainment streaming but does not apply to permanently downloaded entertainment services. ${ }^{34}$ Additionally, according to the petitioners, the expanded amusement tax discriminates against internet-only commerce because it imposes a higher tax rate on performances that are delivered through an online streaming service than it imposes on identical performances that are viewed in person. ${ }^{35}$ Specifically, under the prior interpretation of the law, when live entertainment is performed in an auditorium with a maximum capacity of fewer than 750 people, ticket purchases are exempt from taxation, ${ }^{36}$ and when the auditorium's capacity is more than 750 people, the ticket purchases are taxed

${ }^{30}$ U.S. CONST. art. VI, cl. 2.

${ }^{31}$ Arizona v. United States, 567 U.S. 387, 396-99 (2012).

${ }^{32}$ See Catherine Chen, Note, Taxation of Digital Goods and Services, 70 N.Y.U. ANN. SuRV. AM. L. 421, 434, 450-52 (2015).

${ }^{33} \mathrm{Id}$. at 451.

${ }^{34}$ See Second Amended Complaint, supra note 3, at 85.

${ }^{35} \mathrm{Id}$. at 86 .

${ }^{36} \mathrm{Id}$. at 87 .

Pitt Tax Review | ISSN 1932-1821 (print) 1932-1996 (online) DOI 10.5195/taxreview.2018.74 | http://taxreview.law.pitt.edu 
at a reduced rate of five percent. ${ }^{37}$ However, electronically delivered streaming of the same performances are taxed at nine percent. ${ }^{38}$

This is not the first time that a case like this has arisen and, in certain instances, federal law has prevailed in Illinois. ${ }^{39}$ In 2013, a case, Performance Marketing Ass' $n$ v. Hamer, came before the Supreme Court of Illinois. ${ }^{40}$ That case addressed a challenge to a new Illinois tax law that required out-of-state retailers to collect and remit use tax when in-state persons had websites where a customer could click-through from the person's website to the retailer's website and when the retailer made a minimum of $\$ 10,000$ in sales through these clickable links. ${ }^{41}$ The Illinois "click-through" law appeared to discriminate against internet-only commerce because the law did not apply to sales that were made through advertising over radio or television broadcasts. $^{42}$

In response, a group of performance marketing businesses filed a complaint alleging that Illinois's new laws ${ }^{43}$ were unconstitutional because they required the collection of use taxes on vendors who lacked "substantial nexus" with Illinois and because ITFA preempted the laws. ${ }^{44}$ The Circuit Court agreed with the plaintiffs in regards to both arguments and granted the plaintiffs summary judgment. ${ }^{45}$ The Circuit Court's holding was upheld on appeal. ${ }^{46}$ However, the Supreme Court of Illinois based its decision solely on

${ }^{37}$ Id. at 88 .

${ }^{38}$ Id. at 89 .

${ }^{39}$ See Performance Mktg. Ass'n v. Hamer, 998 N.E.2d 54 (Ill. 2013).

${ }^{40} I d$.

${ }^{41} I d$. at 59 .

${ }^{42}$ Id. at 54

4335 ILl. COMP. Stat. 105/2 (Westlaw through P.A. 100-585 of 2018 Reg. Sess.) (see paragraph 1.1 of the definition of "Retailer maintaining a place of business in this State"); id. at 110/2 (see paragraph 1.1 of the definition of "Serviceman maintaining a place of business in this State"). These laws were referred to as the "Use Tax Act" and the "Service Use Tax Act," respectively, in the statutes.

${ }^{44}$ See Performance Mktg. Ass'n, 998 N.E.2d at 56-57.

${ }^{45} I d$. at 57.

${ }^{46} I d$. at $59-60$.

Pitt Tax Review | ISSN 1932-1821 (print) 1932-1996 (online) DOI 10.5195/taxreview.2018.74 | http://taxreview.law.pitt.edu 


\section{4 |Pittsburgh Tax Review | Vol. 152018}

the preemption argument. ${ }^{47}$ The court did not examine the substantial nexus argument because the court found that the taxes were preempted by ITFA, and thus, concluded its examination. ${ }^{48}$

The arguments made in Performance Marketing Ass' $n$ v. Hamer are very similar to the arguments raised by the petitioners in Labell $v$. City of Chicago. ${ }^{49}$ Additionally, the court in Labell will be required to follow the ruling in Performance Marketing Ass' $n$ v. Hamer if the court determines that the issues in the two cases are the same because Performance Marketing Ass' $n$ v. Hamer was decided by the Supreme Court of Illinois. Performance Marketing Ass' $n$ was decided just three years ago and stands as a recent interpretation of the issue, ${ }^{50}$ and arguably, it would be inconsistent to rule that the extension of the amusement tax is not preempted by ITFA when the taxes in Performance Marketing Ass'n were.

It should be noted that the Circuit Court of Cook County, in Labell, rejected the argument that there were no real and substantial differences between streaming services and live performances and cited to a Supreme Court of Illinois case where a distinction was made between live performances and other entertainment forms. ${ }^{51}$ However, Performance Marketing Ass'n was not cited in the court's opinion and therefore, Performance Marketing Ass' $n$ is a reasonable case for the court to consider on appeal. ${ }^{52}$

Congress has reenacted ITFA many times since its original, albeit temporary, enactment, and thus, reaffirmed its purpose. ${ }^{53}$ Over ITFA's long life, no substantive changes have been made to the law, although changes

${ }^{47} I d$.

${ }^{48} I d$.

${ }^{49}$ See id. at 56; Second Amended Complaint, supra note 3, at 85.

${ }^{50}$ See generally Performance Mktg. Ass'n, 998 N.E.2d 54.

${ }^{51}$ Labell v. City of Chicago, No. 15 CH 13399, slip op. at 3 (Cook Cty. Cir. Ct. May 24, 2018) (citing Pooh-Bah Enterprises, Inc. v. County of Cook, 232 Ill. 2d 463, 496 (2009)).

${ }^{52}$ See id.

${ }^{53}$ JefFery M. Stupak, Cong. Research SerV., R43772, The Internet TAX Freedom ACt: IN BRIEF 1 (2016).

Pitt Tax Review | ISSN 1932-1821 (print) 1932-1996 (online) DOI 10.5195/taxreview.2018.74 | http://taxreview.law.pitt.edu 
have been made to the scope of services covered. ${ }^{54}$ ITFA became permanent in 2016, and therefore, it is not unreasonable to conclude that Congress intends for it to continue to preempt inconsistent state laws. ${ }^{55}$ Moreover, at the most recent House hearings to reenact ITFA, ${ }^{56}$ the Chairman of the House Judiciary Committee, Bob Goodlatte, explained that the internet should continue to be protected from discriminatory taxes even though internet commerce is no longer a new technology. ${ }^{57}$ Proponents of ITFA emphasized that the internet is a place for innovation and should not be subject to additional taxation. ${ }^{58}$

As a result, an extension of the law relating to the amusement tax reasonably appears to be inconsistent with what Congress intended and recently reaffirmed. ${ }^{59}$ The petitioners' argument that the amusement tax must be struck down because it is preempted by ITFA is logical for the reasons presented in the brief and can be argued on additional grounds.

\section{CONSTITUTIONALITY CONCERNS REGARDING THE EXPANDED AMUSEMENT TAX}

The petitioners' argument that the expanded amusement tax is unconstitutional also carries some strength. States are limited in their abilities to tax by the U.S. Constitution, specifically by the Due Process Clause and the Commerce Clause. ${ }^{60} \mathrm{~A}$ tax is only constitutional if the Due Process

${ }^{54} \mathrm{Id}$.

${ }^{55}$ Trade Facilitation and Trade Enforcement Act of 2015, Pub. L. No. 114-125, § 922(a), 130 Stat. 122, 281 (2016).

${ }^{56}$ See 161 CONG. REC. H3952 (daily ed. June 9, 2015) (statement of Rep. Goodlatte) (rejecting a growing belief that the internet is no longer entitled to superior protections: "They argue that the Internet is no longer a fledgling technology in need of protection. But it is precisely the ubiquity of the Internet that counsels for a permanent extension. It has become an indispensable gateway to scientific, educational, and economic opportunities.").

${ }^{57} \mathrm{Id}$.

${ }^{58}$ Id. at $\mathrm{H} 3954$ (statement of Rep. Chabot).

${ }^{59}$ See Trade Facilitation and Trade Enforcement Act $\$ 922(a)$.

${ }^{60}$ Eric S. Smith, The PACT Act as Indicium of the Due Process Validity of the Marketplace Fairness $A c t, 19$ Fla. TAX REV. 1, 5 (2016); U.S. CONST. art. I, § 8, cl. 3; see id. amend. XIV.

Pitt Tax Review | ISSN 1932-1821 (print) 1932-1996 (online) DOI 10.5195/taxreview.2018.74 | http://taxreview.law.pitt.edu 


\section{6 |Pittsburgh Tax Review | Vol. 152018}

Clause and Commerce Clause requirements are met ${ }^{61}$ However, many laws targeting online retailers arguably do not meet the requirements of the Due Process and Commerce Clauses.

Under the Due Process Clause of the U.S. Constitution, a business must have a minimum connection with a state to be subject to taxation within that state. ${ }^{62}$ This means that a business must be on notice that they could be taxed within the state by purposefully availing themselves of the market in that state. ${ }^{63}$ The Due Process Clause test is a low threshold to meet. ${ }^{64}$ Many companies, when examined, will be found to have met the Due Process Clause requirement of "minimal connections." 65

The Commerce Clause of the U.S. Constitution is more restrictive on states' abilities to tax businesses. ${ }^{66}$ The Commerce Clause grants Congress the power to regulate interstate commerce. ${ }^{67}$ Implied in the Commerce Clause is the dormant Commerce Clause, which prohibits states from enacting laws that burden or frustrate interstate commerce. ${ }^{68}$ Thus, the dormant Commerce Clause would be violated if a state's taxation of internet retailers interferes with interstate commerce. ${ }^{69}$ The Commerce Clause is interpreted by the Supreme Court to require businesses to have a "substantial nexus" in a state to be subject to taxation in that state. ${ }^{70}$ The substantial nexus threshold is met when a business has sufficient contacts or physical presence

${ }^{61}$ See Quill Corp. v. North Dakota, 504 U.S. 298, 318-19 (1992).

${ }^{62}$ U.S. CONST. amend. XIV; Miller Bros. Co. v. Maryland, 347 U.S. 340, 344-45 (1954).

${ }^{63}$ See Quill, 504 U.S. at 298.

${ }^{64}$ See id.

${ }^{65}$ See id.

${ }^{66}$ See id. at 312.

${ }^{67}$ U.S. CONST. art. I, § 8, cl. 3.

${ }^{68}$ Lauren Joseph Wolongevicz, Comment, New Mexico Taxation \& Revenue Department v. Barnesandnoble.com LLC: Reconsidering the Dormant Commerce Clause in an E-Commerce World, 91 DENV. U. L. REV. 741, 743 (2014).

${ }^{69} \mathrm{Id}$.

${ }^{70}$ See Sara Schoenfeld, Note, Much Ado About Nexus: The States Struggle to Impose Sales Tax Obligations on Out-of-State Sellers Engaged in E-Commerce, 24 FORDHAM INTELL. PROP. MEDIA \& ENT. L.J. 263, 266 (2013).

Pitt Tax Review | ISSN 1932-1821 (print) 1932-1996 (online) DOI 10.5195/taxreview.2018.74 | http://taxreview.law.pitt.edu 
in a state. ${ }^{71}$ When this threshold is met, the business can be subject to taxation by that state. ${ }^{72}$

There is a variety of case law at the Supreme Court level, over many years, addressing the type of "presence" that is required within a jurisdiction for an entity to be subject to taxation within that jurisdiction under the Commerce Clause. In 1967, the Supreme Court ruled in National Bellas Hess v. Department of Revenue that some physical presence is required in a state to subject a retailer to collect and remit taxes when they make sales to customers within that state. ${ }^{73}$

Ten years after National Bellas Hess, the Supreme Court in Complete Auto Transit, Inc. v. Brady applied a four-prong test to determine a business's taxability under the Commerce Clause. ${ }^{74}$ The four prongs examined are: (1) if the taxpayer's activity had a substantial nexus within the state, (2) if the tax was nondiscriminatory between interstate and intrastate commerce, (3) if the tax was properly apportioned, and (4) whether the tax was fairly related to services provided by the state. ${ }^{75}$ All four of the prongs must be met in order for a tax to be constitutional. ${ }^{76}$ The petitioners in Labell argue that none of the prongs have been met. ${ }^{77}$

Under the first prong, substantial nexus between streaming service providers and Chicago may not be clear enough to impose the amusement tax. To meet the substantial nexus requirement in a jurisdiction, the company must have made the requisite contacts with that state. ${ }^{78}$ As noted by the petitioners, online streaming of video, audio, and gaming do not have a

\footnotetext{
${ }^{71}$ See Quill, 504 U.S. at 298.

${ }^{72}$ See id.

${ }^{73}$ See Nat'1 Bellas Hess v. Dep't of Revenue, 386 U.S. 753, 758 (1967).

${ }^{74}$ Complete Auto Transit, Inc. v. Brady, 430 U.S. 274, 279 (1977).

${ }^{75} \mathrm{Id}$.

${ }^{76} I d$.

${ }^{77}$ Second Amended Complaint, supra note 3, at 105-08.

${ }^{78}$ Tyler Pipe Indus. v. Wash. State Dep't of Revenue, 483 U.S. 232, 253 (1987).
}

Pitt Tax Review | ISSN 1932-1821 (print) 1932-1996 (online) DOI 10.5195/taxreview.2018.74 | http://taxreview.law.pitt.edu 


\section{8 |Pittsburgh Tax Review | Vol. 152018}

substantial nexus with Chicago because the activities occur online and not in Chicago. $^{79}$

The second prong is not met because the expanded amusement tax imposes a higher tax rate on entertainment that is delivered through an online streaming service provided by out-of-state retailers than it imposes on identical performances viewed live in Chicago. ${ }^{80}$

Under the third prong, the expanded amusement tax ignores apportionment because it requires that the entire transaction be "apportioned" and remitted to Chicago, even if the only thing that connects that transaction to Chicago is the purchaser's billing address. It is plausible to imagine a situation where a taxpayer orders his subscription in New York, bills the subscription to Chicago, and watches or uses his subscription in Philadelphia. In this example, it does not seem fair that the entire transaction should be apportioned to Chicago. However, the tax imposed under the expanded amusement tax does not recognize other jurisdictions that were related to, or a part of, the transaction.

Under the fourth prong, many streaming service providers that are subject to this tax do not enjoy any protections from Chicago's services because their only connection with Chicago is their customers who unilaterally contact the online retailers to order subscriptions and have billing addresses in Chicago. ${ }^{81}$ As a result, the petitioners reasonably argue that the expanded amusement tax has not met the Commerce Clause's four-prong test. Therefore, even if the expanded amusement tax meets the Due Process Clause's requirements, it is likely unconstitutional because it has not satisfied all four prongs of the Commerce Clause.

\section{OTHER CONSIDERATIONS}

The issue at hand is unique because the amusement tax imposes a tax on individuals who purchase subscriptions of online entertainment sources in Chicago, but it does not differentiate between its citizens who watch their

\footnotetext{
${ }^{79}$ Second Amended Complaint, supra note 3, at 105.

${ }^{80} \mathrm{Id}$. at 107.

${ }^{81} I d$. at 108.
}

Pitt Tax Review | ISSN 1932-1821 (print) 1932-1996 (online) DOI 10.5195/taxreview.2018.74 | http://taxreview.law.pitt.edu 
subscriptions in Chicago from those who do not. ${ }^{82}$ Specifically, it does not consider the location where the entertainment is consumed, even though the amusement tax prior to the expansion "applies only to activity (i.e., the amusement) that takes place within Chicago." ${ }^{83}$ For the expanded amusement tax, taxability is determined solely based upon the purchaser's billing address. ${ }^{84}$

As the expanded amusement tax currently stands in Chicago, $100 \%$ of the cost of online subscription purchases are taxable in Chicago when purchased by a taxpayer with a billing address in Chicago. However, if other states begin to enact expanded amusement taxes, some states could reasonably require taxation where a subscription is watched, ordered, or billed. ${ }^{85}$ This could require states to split, or apportion, their tax proceeds with other states that also play a role in these transactions. ${ }^{86}$ If multiple states do not uniformly enact amusement taxes, and the question of apportionment is not resolved, double taxation of one transaction may also be a concern. ${ }^{87}$

In addition to constitutional questions and ITFA preemption concerns, there are other concerns associated with the expanded amusement tax. Chicago, and other cities contemplating the adoption of taxes imposed on online entertainment subscriptions, ${ }^{88}$ may be compelled to adopt such taxes

${ }^{82}$ See The City of Chicago Moves Aggressively to Tax “The Cloud,” ReEd SMith: CLIENT AlERTS (June 17, 2015) [hereinafter REED SMITH CLIENT ALERT], https://www.reedsmith.com/The-City-ofChicago-Moves-Aggressively-to-Tax-The-Cloud-06-17-2015/.

${ }^{83}$ See id.; Chi. Dep't of Fin., supra note 1 (considering nexus concerns but saying that they are "beyond the scope of this ruling").

${ }^{84}$ See ReEd Smith Client Alert, supra note 82.

${ }^{85}$ See GMC v. Dep’t of Taxation, 602 S.E.2d 123, 125 (Va. 2004) (explaining that “" $\left.\mathrm{t}\right]$ he ... taxable income of a financial corporation ... shall be apportioned within and without this Commonwealth in the ratio that the business within this Commonwealth is to the total business of the corporation. Business within this Commonwealth shall be based on cost of performance in the Commonwealth over cost of performance everywhere.").

${ }^{86}$ See id.

${ }^{87}$ Id.; see Butler Bros. v. McColgan, 315 U.S. 501, 503 (1942). Apportionment methods should aim to avoid double taxation.

${ }^{88}$ See "Netflix Tax" Goes into Effect in Pennsylvania, CBS PitTSBuRgh (Aug. 1, 2016, 3:01 PM), http://pittsburgh.cbslocal.com/2016/08/01/netflix-tax-goes-into-effect-in-pennsylvania/. Pennsylvania recently enacted a six percent tax, deemed a "Netflix Tax," in an attempt to close a gap in the state's budget. Pennsylvania's new tax is technically the extension of the sales tax to include digital purchases.

Pitt Tax Review | ISSN 1932-1821 (print) 1932-1996 (online) DOI 10.5195/taxreview.2018.74 | http://taxreview.law.pitt.edu 
because the tax has the potential to expedite financial growth in the short term. However, the expanded amusement tax does not address the cities' larger financial problems. ${ }^{89}$ Therefore, it may not be the best way to reach the city's goals.

Extreme expansions in tax laws, as Chicago arguably has done with the current amusement tax, lack predictability and companies' budgets may not be prepared to adapt to such changes. ${ }^{90}$ People and businesses tend to act in certain ways because of the corresponding tax implications. ${ }^{91}$ It is important to have a tax system that is predictable and not unfair to those who are subject to it. ${ }^{92}$ This concern could have been better addressed if Chicago, acting through City Council, had passed a new ordinance to tax online entertainment subscription purchases. It was unpredictable that the already existing amusement tax would be expanded through the issuance of a ruling.

While it may not appear to be "bad" to tax online entertainment purchases, a growing concern is what features of the internet could be taxed next if jurisdictions begin to tax online subscription purchases. ${ }^{93} \mathrm{~A}$ tax

Like the extended amusement tax in Chicago, the Pennsylvania tax is triggered when an online subscription is purchased with a Pennsylvania billing address. However, the Pennsylvania tax also has some complexities. For example, it taxes the purchases of subscriptions such as Netflix and Hulu, and it taxes entertainment sources like games, ringtones, e-books, and music. However, it explicitly excludes online purchases such as magazines, newspapers, and digital Bibles from taxation. This could make for challenging compliance with the tax as it requires line drawing to define "entertainment" and what is excluded from taxation. However, a compelling argument in favor of the tax is that the six percent tax in Pennsylvania raised \$46.9 million in revenue during its first ten months. Mark Snider, A "Netflix Tax"? Yes, It's Already a Thing in Some States, USA TODAY (Aug. 17, 2017, 8:30 AM), https://www.usatoday .com/story/tech/news/2017/08/17/netflix-tax-yes-and-its-already-thing-some-states/500416001/.

California is among states also considering adding a "Netflix Tax." Mike McPhate, California Today: Fretting over "Netflix Tax," N.Y. TIMES: CAL. TODAY (Nov. 28, 2016), http://www.nytimes.com/2016/ 11/28/us/california-today-netflix-tax-video-streaming.html?smprod=nytcore-iphone\&smid=nytcoreiphone-share\&_r=0. Roughly forty cities in California are also considering adding a "Netflix Tax" to consumers' streaming service bills.

${ }^{89}$ Travis H. Brown, Chicago to Apply 9\% “Netflix Tax,” ForbeS (July 8, 2015, 9:51 AM), http://www.forbes.com/sites/travisbrown/2015/07/08/chicago-to-apply-9-netflix-tax/\#108fb85b27a6.

${ }^{90}$ Sidney S. Silhan, Note, Fresh Looks: If It Ain't Broken Don't Fix It: An Argument for the Codification of the Quill Standard for Taxing Internet Commerce, 76 CHI.-KENT L. REV. 671, 677 (2000).

${ }^{91}$ See 161 Cong. REC. H3952 (daily ed. June 9, 2015) (statement of Rep. Goodlatte) (“The Permanent Internet Tax Freedom Act converts the moratorium into a permanent ban - on which consumers, innovators, and investors can permanently rely—by simply striking the 2015 end date.").

$$
\begin{aligned}
& { }^{92} I d . \\
& { }^{93} I d .
\end{aligned}
$$

Pitt Tax Review | ISSN 1932-1821 (print) 1932-1996 (online) DOI 10.5195/taxreview.2018.74 | http://taxreview.law.pitt.edu 
imposed on reading an email or completing an internet search for educational research purposes appears to be much more burdensome than taxing purchases of entertainment streamed online. Despite the distinction between online entertainment and other online activities, if the expanded amusement tax is found to be permissible, states could more easily rationalize the taxation of any online activity, regardless of its nature. Whether Chicago's expanded amusement tax is upheld in court could be very telling as to whether other states and local governments decide to create their own amusement taxes or other taxes imposed upon different internet-based activities.

\section{CONCLUSION}

A reasonable argument can be made, as presented by the petitioners, that Chicago's comptroller exceeded the scope of his authority when he expanded Chicago's amusement tax in the Ruling. If the city wished to tax purchases of online entertainment, the city should have passed a new ordinance. In addition, the petitioners' arguments that the expanded amusement tax is likely preempted by ITFA, as it is applied, and that the expanded amusement tax is unconstitutional under the Commerce Clause are also reasonable arguments. Viewed in totality, there are ample reasons for the appellate court to find in favor of the petitioners in Labell.

Pitt Tax Review | ISSN 1932-1821 (print) 1932-1996 (online) DOI 10.5195/taxreview.2018.74 | http://taxreview.law.pitt.edu 